\title{
GAYA BAHASA DAN NILAI PENDIDIKAN KARAKTER DALAM KUMPULAN CERPEN DILARANG MENCINTAI BUNGA-BUNGA KARYA KUNTOWIJOYO SEBAGAI MATERI AJAR DI SMP
}

\author{
Dimas Pramudya Nugroho, Sumarwati, Edy Suryanto \\ Universitas Sebelas Maret \\ Surel: dmznugraha@gmail.com,watik_uns@ymail.com
}

\begin{abstract}
Abstrak: Penelitian ini merupakan penelitian deskriptif kualitatif. Teknik pengambilan sampel dilakukan dengan menggunakan purposive sampling. Validitas data menggunakan triangulasi metode.. Hasil penelitian: (1) Penggunaan gaya bahasa dalam kumpulan cerpen Dilarang Mnencintai Bunga-Bunga ditemukan 12 jenis gaya bahasa yang mendominasi dan gaya bahasa hiperbola paling mendominasi; (2) Penggunaan citraan dalam kumpulan cerpen Dilarang Mencintai Bunga-Bunga ditemukan 4 bentuk citraan dan citraan penglihatan yang paling mendominasi; (3) Ditemukan 5 nilai penguatan pendidikan karakter dalam kumpulan cerpen Dilarang Mencintai Bunga-Bunga yang dapat diteladani oleh pembaca. Nilai pendidikan karakter yang terdapat dalam Kumpulan Cerpen Dilarang Mencintai Bunga-Bunga terdiri dari 5 macam, yaitu religius, mandiri, integritas, nasionalis dan gotong royong. dan (4) Kumpulan cerpen Dilarang Mencintai Bunga-Bunga memiliki kriteria kesesuaian cerpen yang dapat digunakan sebagai materi ajar yaitu: a) bahasanya ringan, mudah dimengerti peserta didik; b) sesuai dengan umur, minat, dan perkembangan kejiwaan; c) sejalan dengan lingkungan sosial budaya peserta didik; d) memupuk rasa keingintahuan. Implementasi hasil penelitian kumpulan cerpen Dilarang Mencintai Bunga-Bunga sebagai bahan ajar sastra di SMP relevan dengan Kompetensi Inti dan Kompetensi Dasar.
\end{abstract}

Kata kunci: cerpen, gaya bahasa, nilai penguatan pendidikan karakter, bahan ajar

\section{STILISTIC AND CHARACTER EDUCATION VALUES IN DILARANG MENCINTAI BUNGA-BUNGA ANTHOLOGY OF SHORT STORIES BY KUNTOWIJOYO AS LEARNING MATERIALS IN JUNIOR HIGH SCHOOL}

\begin{abstract}
This research is a qualitative descriptive study. The sampling technique is done by using purposive sampling. Data validity using triangulation method. Data analysis techniques in this study using interactive analysis techniques: (1) data reduction; (2) data presentation; (3) drawing conclusions. The results of research: (1) The use of stylistic in an ontology of short stories Dilarang Mencintai Bunga Bunga, 12 types of dominant language stylistic are found and the most dominating is hyperbole stylistic; (2) The use of imagery in ontology of short stories Dilarang Mencintai Bunga-Bunga. it is found 4 forms of imageries and the most dominating is vision; (3) it is found 5 values of character education building in an ontology of short stories Dilarang Mencintai Bunga-Bunga namely: a) religious; b) independent; c) integrity; d) community selfhelp; e) nationalist; and (4) The ontology of short stories Dilarang Mencintai Bunga Bunga has the suitability criteria that can be used as teaching materials that are: a) the language is light, easy to understand; b) suitable with age, interest, and psychological development; c) suitable with the socio-cultural environment of learners; d) enhance sense of curiosity. Implementation of research results. The ontology of short stories Dilarang Mencintai Bunga Bunga as literature materials in junior high school is relevant to Core Competence and Basic Competence.
\end{abstract}

Keywords: short story, style of language, the value of strengthening character education, teaching materials

BASASTRA Jurnal Bahasa, Sastra, dan Pengajarannya

Volume 7 Nomor 1, April 2019, ISSN I2302-6405 


\section{PENDAHULUAN}

Sastra adalah suatu kegiatan kreatif, sebuah karya seni (Wellek dan Austin Warren, 2014:3). Melalui sastra, orang dapat mengidentifikasi perilaku dan karakater masyarakat, bahkan mengenali budaya masyarakat penduduknya (Riris K., 2010:v). Sastra Indonesia merupakan cermin kehidupan masyarakat Indonesia Sebuah karya sastra bukanlah hasil karangan ataupun imajinasi belaka, tetapi karya sastra merupakan wujud dari pemikiran, perenungan, dan penghayatan terhadap sebuah realitas sosial yang terjadi.

Karya sastra juga harus bersifat estetik dan memberikan kepuasan bagi penikmatnya. Karya sastra juga harus dapat meninggalkan kesan bagi pembacanya supaya pembaca dari karya sastra tersebut dapat ikut merasakan sendiri seluruh aspek dirinya dalam sebuah karya sastra dan dapat melakukan kegiatan dari pengalaman itu. Pendek kata sastra yang baik harus memberikan 'sesuatu' pada pembaca sehingga ia menjadi semakin arif dalam hidup (Sumardjo, 1982: 22).

Menurut Sayuti, karya sastra menurut ragamnya dibedakan menjadi tiga, yaitu prosa, puisi dan drama. Novel, cerpen, novelet, cerita bersambung (cerbung) merupakan bagian dari prosa. Cerpen merupakan karangan fiktif yang berisi sebagian kehidupan seseorang atau kehidupan yang berfokus pada suatu tokoh. ciri cerpen antara lain; singkat, padu, memiliki unsur utama berupa adegan, tokoh, dan gerak, bahasanya tajam, serta menarik perhatian. Cerpen menurut Poe merupakan karya prosa fiksi yang dapat selesai dibaca dalam sekali duduk. Sebagai sebuah karya imajiner, cerpen mangandung berbagai persoalan manusia dan kehidupan.

Cerpen atau cerita pendek sebagai suatu karya seni berfungsi sebagai notulen kehidupan. Pengarang dengan daya imajinasi yang dimilikinya tidak akan bisa tertidur dengan nyaman sebelum semua peristiwa itu ditulis, yang akhirnya dapat dibaca, dipahami, dan direntangkan oleh siapa saja. Dengan demikian, apabila seorang membaca cerpen diharapkan dapat mengetahui seluk beluk peristiwa kehidupan, tanpa merasa digurui. Diantara peristiwa kehidupan itu adalah kebahagiaan, keindahan alam, kemajuan teknologi, kesenjangan sosial, kegelisahan batin pada orang-orang yang tertindas, harapan, kekecewaan, keadilan, kekejaman, kemiskinan yang teramat parah atau kekayaan yang berlimpah ruah, kehancuran di masa lalu atau harapan yang menggebugebu untuk masa depan, dan lain-lain. Sebagai dokumentasi, cerpen bagaikan cermin yang memperlihatkan peristiwa tersebut (Nuroh, 2011: 22).

Dalam dunia sastra di Indonesia, nama Kuntowijoyo sudah tidak asing lagi. Selain dikenal sebagai ilmuwan sosial, sejarawan, cendekiawan muslim, beliau juga dikenal sebagai sastrawan yang handal. telah banyak karya sastra yang dihasilkan olehnya, baik berupa novel, cerpen, maupun sajak yang telah ia buat. Salah satu karya terkenal yang berupa cerpen yaitu "Dilarang Mencintai BungaBunga", memperoleh hadiah pertama dalam majalah Sastra tahun 1968, berupa kumpulan cerpen yang menyoroti kehidupan masyarakat pedesaan dalam kaitannya soal keimanan. dalam melukiskan kehidupan dan masalahnya, dia menggunakan pendekatan yang unik.

Setiap pengarang mempunyai konsep berbeda-beda dalam melahirkan suatu cipta sastra. Hal ini disebabkan adanya berbagai keanekaragaman dan gaya bahasa tiap penulis. Salah satu cara untuk mengetahui kekhasan penulisan setiap pengarang dalam karya sastra adalah dengan meneliti kekhasan penggunaan bahasa yang digunakan setiap pengarang dalam membuat karyakaryanya. Pengkajian mengenai kekhasan pemakaian bahasa dalam suatu karya sastra dikaji dengan pendekatan stilistika. Stilistika 
merupakan ilmu yang berkaitan dengan gaya (style) tetapi pada umumnya lebih banyak mengacu pada gaya bahasa, bagaimana segala sesuatu diungkapkan dengan cara tertentu sehingga tujuan yang dimaksudkan dapat tercapai secara maksimal (Ratna, 2009:3).

Gaya bahasa masing-masing pengarang dalam membuat karya sastra tentu berbeda. Salah satu kekhasan penggunaan bahasa antara lain diperlihatkan oleh Kuntowijoyo melalui kumpulan cerpen Dilarang Mencintai Bunga-Bunga. Kekhasan gaya bahasa Kuntowijoyo melalui kumpulan cerpen Dilarang Mencintai Bunga-Bunga sangat menarik untuk diteliti. Kumpulan Cerpen tersebut syarat dengan konflik, ditulis dengan pengemasan bahasa yang sederhana namun amat memikat. Kuntowijoyo sangat pandai menggunakan pemilihan bahasa untuk menggambarkan karakter dan suasana hati tokoh. Dengan bahasa yang sederhana, pengarang berhasil mengajak pembacanya seolah turut dalam cerita pada setiap alurnya. Berbagai problematika dihadapi oleh tokoh utama dengan pengemasan bahasa yang sederhana, sehingga membuat cerpen ini lebih hidup. Sehingga menarik untuk diteliti dalam hal gaya bahasa dan citraan.

Sastra bukan hanya sebagai pewaris budaya semata sebab di dalamnya juga terkandung nilai-nilai pendidikan. Ragam pendidikan yang terkandung dalam katya sastra lembut menyentuh nurani pembacanya, serta tidak terdapat unsur memaksakan. Selain kajian stislistika terutama dalam gaya bahasa dan citraan dalam cerpen Dilarang Mencintai Bunga syarat akan nilai pendidikan karakter yang ada di dalam nya. Pendidikan karakter bertujuan untuk menguatkan dan mengembangkan nilai-nilai kehidupan yang dianggap penting dan perlu. Penguatan pendidikan karakter dalam konteks sekarang sangat relevan untuk mengatasi krisis moral yang sedang terjadi pada siswa yang ada di Indonesia. Manfaatnya untuk membentuk kepribadian/kepemilikan yang khas sebagaimana nilai-nilai yang dikembangkan, mengoreksi perilaku yang tidak bersesuaian dengan nilai-nilai yang dikembangkan oleh sekolah, dan membangun koneksi yang harmoni dengan keluarga dan masyarakat dalam memerankan tanggung jawab pendidikan karakter secara bersama. Nilai yang perlu diperkuat untuk pembangunan bangsa saat ini yaitu Relijius, Nasionalis, Mandiri, Integritas dan gotong royong. Nilai-nilai penguatan pendidikan karakter yang akan akan diteliti Relijius, Nasionalis, Mandiri, Integritas, gotong royong.

\section{METODE PENELITIAN}

Penelitian ini merupakan penelitian deskriptif kualitatif dengan pendekatan kualitaif dengan pendekatan analisis isi (content analysis). Penelitian ini termasuk dalam jenis penelitian kualitaif yang menurut Bogdan(Moloeng,2010) merupakan penelitian yang menghasikan data deskriptif berupa kata-kata tertulis. Teks sastra yang dikaji dideskripsikan secara sistematis. Adapun pendekatan analisis isi menurut Krippendorff (2004:18) merupakan teknik penelitian untuk membuat tiruan dan kesimpulan yang valid dari teks (atau masalah yang lain) ke konteks penggunaannya.

Data dan sumber data dalam penelitian ini yaitu berupa dokumen ( Dilarang Mencintai Bunga-bunga) dan informan. Dokumen yang digunakan dalam penelitian ini adalah kumpulan cerpen Dilarang Mencintai Bunga-bunga Karya Kuntowijoyo diterbitkan oleh penerbit Noura Publishing dengan tebal 292 halaman . Adapun informan dalam penelitian ini adalah guru SMP dan peserta didik SMP.

Teknik pengambilan sampel dalam penelitian ini menggunakan purposive sampling. Teknik ini berarti telah 
menentukan sampel berdasarkan pertimbangan tertentu yang didasarkan dari tujuan penelitian. Teknik pengumpulan ddata dalam penelitian ini adalah analisis dokumen dan wawancara. Uji validitas yang digunakan adalah triangulasi teori dan triangulasi sumber data. Analisis data yang digunakan adalah model interaktif yang di dalamnya terdapat 3 komponen analisis, yaitu: 1) reduksi data; 2) penyajian data; 3) penarikan kesimpulan.

\section{HASIL DAN PEMBAHASAAN PENELITIAN \\ Gaya Bahasa}

Menurut Aminuddin (1995: 4), style diartikan sebagai teknik serta bentuk gaya bahasa seseorang dalam memaparkan gagasan sesuai dengan ide dan norma yang digunakan sebagaimana ciri pribadi pemakainya. Sebelum memiliki stilistika, bahasa dalam karya sastra memang telah memiliki gaya. Endraswara (2003: 71) menjelaskan bahwa gaya adalah segala sesuatu yang "menyimpang" dari pemakaian biasa. Penyimpangan tersebut bertujuan untuk keindahan. Keindahan ini banyak muncul dalam karya sastra, karena sastra memang sarat dengan unsur estetik. Segala unsur estetik ini menimbulkan manipulasi bahasa, plastik bahasa, dan kado bahasa sehingga mampu membungkus rapi gagasan penulis. Ali, Waluyo, dan Anindyarini (2012: 110) menambahkan gaya bahasa mempergunakan bahasa yang indah untuk meningkatkan efek dengan jalan memperkenalkan serta memperbandingkan suatu benda atau hal tertentu dengan benda, atau hal lain yang lebih umum. Penggunaan gaya bahasa tentu saja meningkatkan kekayaan kosakata pembaca dengan sendirinya.

Gaya pada hakikatnya merupakan teknik pemilihan ungkapan kebahasaan yang dirasa dapat mewakili sesuatu yang akan diungkapkan oleh pengarang. Teknik itu sendiri merupakan bentuk pilihan yang dapat dilihat pada bentuk ungkapan suatu bahasa seperti yang dipergunakan dalam sebuah karya sastra

Pada penelitian ini, ditemukan data permajasan sejumlah 74 data. Data permajasan tersebut merupakan data dari beberapa kelompok majas, yaitu simile sejumlah 8, metafora sejumlah 10 , personifikasi sejumlah 12, alegori sejumlah 5, antitesis sejumlah 3, sarkasme sejumlah 5 , epitet sejumlah 3 , hiperbola sejumlah 13, asonansi sejumlah 5, paradoks sejumlah 2, klimaks sejumlah 2 , antiklimaks sejumlah 1 , sinisme sejumlah 3 , parafrasis sejumlah 2, pleonasme sejumlah 2.

Ada tiga majas yang dominan dalam novel Dilarang Mencintai Bunga-Bunga karya Kuntowijoyo, yaitu metafora,personifikasi, dan hiperbola. Contoh penggunaan majas (1) Hiperbola, (2) Personifikasi, (3) Metafora pada cerpen Dalam cerita pendek Ikan-Ikan Dalam Sendang

\section{Hiperbola}

Hiperbola adalah semacam gaya bahasa yang mengandung suatu pernyataan yang berlebihan dengan membesarbesarkan suatu hal. Keraf (2010: 135)

Hingga, bahkan jantungnya serasa ditusuk, darah mengalir lebih keras. (DMBB, 2016: 59).

Data (6) terdapat majas hiperbola karena mempunyai makna berlebihan. Hal ini ditunjukkan dengan keadaan dari jantungnya yang tiba-tiba terkejut karena mantra yang ia ucapkan tidak bekerja kepada orang yang ada di dalam rumah sampai ia merasa bahwa jantungnya seperti ditusuk dan merasakan sakit yang begitu luar biasa. 


\section{Personifikasi}

Personifikasi adalah pengungkapan dengan menyampaikan benda mati atau tidak bernyawa sebagai manusia (Agni, 2009: 109).

Tidak berlebihan menyebut bahwa kakinya punya mata lebih tajam dari mata yang tergantung di keningnya (DMBB, 2016: 152).

Data (1) merupakan majas personifikasi karena menyebut bahwa benda mati seolah-olah mempunyai sifat seperti manusia. Hal ini ditunjukkan dengan kaki yang dianggap memiliki sebuah mata yang lebih tajam dari mata pada umumnya.

\section{Metafora}

Metafora adalah pengungkapan berupa perbandingan analogis dengan menghilangkan kata 'layaknya, bagaikan, dan lain-lain' (Agni, 2009: 107

Karena mata batinku lebih tajam dari mata kepalaku. (DMBB, 2016: 7)

Gaya bahasa metafora dalam kalimat ini terletak pada "mata batin", kutipan ini menunjukkan adanya majas metafora yang berarti perasaan

\section{Citraan}

Salah satu cara untuk menyampaikan gagasan yang dituliskan kepada pembaca yakni melalui citraan. Berdasarkan hal tersebut, Nurgiyantoro (2014: 278) membagi citraan kata menjadi tujuh jenis, yaitu: (a) citraan penglihatan, (b) citraan pendengaran, (c) citraan penciuman, (d) citraan pengecapan, (e) citraan gerak, dan (f) citraan perabaan

Pradopo (1993: 79) mengatakan, gambaran-gambaran angan dalam sajak itu disebut citraan (imagery). Untuk menggambarkan tulisan yang ditulis oleh penulis maka perlulah suatu citraan di dalamnya. Citraan tersebut harus dapat diterima oleh pembaca supaya pembaca dapat memahami makna yang terkandung dalam karya sastra melalui gambarangambaran (citraan). Pradopo (1993: 80) menegaskan, gambaran pikiran adalah sebuah efek dalam pikiran yang sangat menyerupai (gambaran) yang dihasilkan oleh penangkapan kita terhadap suatu objek yang dapat dilihat oleh mata, saraf penglihatan, dan daer Citraan merupakan gambaran sesuatu yang dituturkan menjadi lebih konkret, mudah dibayangkan, mudah diimajikan, dan karenanya juga menjadi lebih mudah dipahami

Dari pendapat di atas, maka terdapat beberapa analisis dari penggunaan citraan kumpulan cerita pendek Dilarang Mencintai Bunga-Bunga jika di prosentasekan citraan pengelihatan $37 \%$, citraan pendengaran $22 \%$, citraan penciuman 5\%, Citraan pengecapan 5\%

Contoh Penggunaan Citraan pengelihatan dalam Kumpulan cerpen Dilarang mencintai bunga-bunga.

Sebuah gerakan dalam air. (BMBB, 2011: 160).

Data (1) merupakan citraan penglihatan. Hai ini ditunjukkan oleh pandangan mata yang melihat adanya gerakan di dalam air.

\section{Nilai Penguatan Pendidikan Karakter}

Terdapat nilai penguatan pendidikan karakter dalam Kumpulan Cerpen Dilarang Mencintai Bunga-Bunga karya Kuntowijaya antralain adalah nilai religius, mandiri, integritas, nasionalis dan gotong royong. . Dalam Peraturan Presiden No. 87 Tahun 2017 pasal 1 tentang penguatan pendidikan karakter Terdapat lima karakter utama yang bersumber dari pancasila, yang menjadi prioritas pengembang gerakan Penguatan Pendidikan karakter, yaitu Nasionalisme, Integritas, Kemandirian, dan 
gotong royong. Masing-masing nilai tidak berdiri dan berkemabang sendiri-sendiri, melainkan salingberinteraksi satu sama lain, berkemabang secara dinamis dan membentuk keutuhan pribadi.

Pada Kumpulan Cerpen Dilarang Mencintai Bunga-Bunga ini mengandung nilai-nilai pendidikan karakter yang dapat diteladani oleh pembaca. Nilai pendidikan karakter yang terdapat dalam Kumpulan Cerpen Dilarang Mencintai Bunga-Bunga terdiri dari 5 macam, yaitu religius, mandiri, integritas, nasionalis dan gotong royong. Nilai-nilai tersebut dapat menjadi dasar bagi pembaca dalam bersikap dan berperilaku sehingga dapat membentuk watak dan kepribadian yang berbudi luhur . Dan Bermanfaat untuk membentuk kepribadian/kepemilikan yang khas sebagaimana nilai-nilai yang dikembangkan, mengoreksi perilaku yang tidak bersesuaian dengan nilai-nilai yang dikembangkan oleh sekolah, dan membangun koneksi yang harmoni dengan keluarga dan masyarakat dalam memerankan tanggung jawab pendidikan karakter secara bersama.

Contoh penggunaan nilai penguatan pendidikan Gotong royong karakter Dalam Cerpen Anjing

Kita tidak dapat melarang apa-apa pada tetangga atau menyuruhnya berbuat apa yang kita suka, sebab mereka mempunyai juga hak asasi sebagai manusia dan sebagai warga negara yang dijamin undang-undang." (DMBB, 2016:33). Kutipan diatas mencerminkan menghargai sesama.

\section{Relevansi sebagai Bahan Pengajaran Sastra di SMA}

Kumpulan Cerpen Dilarang Mencintai Bunga-Bunga jika dikaitkan dengan materi pembelajaran bahasa Indonesia pada kelas IX Sekolah Menengah Pertama (SMP) Dalam silabus pembelajaran Bahasa Indonesia kelas IX
SMP terdapat KD 3.3 yaitu 'Menganalisis teks cerita pendek, baik melalui lisan maupun tulisan.' Sependapat dengan Nina, dalam silabus tertuliskan bahwa materi pokok yang harus diajarkan oleh siswa mengenai: (1) Analisis bahasa teks cerita pendek; (2) Penyuntingan isi sesuai dengan struktur isi teks cerita pendek; dan (3) Penyuntingan bahasa sesuai dengan: struktur kalimat, ejaan, dan tanda baca.

Kisah kepolosan yang diceritakan dari sudut pandang anak kecil dapat menjadi poin tambahan ketika menggunkaan Kumpulan Cerpen Dilarang Mencintai Bunga-Bunga sebagai materi pengajara sastra. Penggunaan bahasa Indonesia dan pemilihan gaya bahasa yang bagus juga menjadi pertimbangan novel tersebut untuk dijadikan sebagai materi pengajaran, karena mudah dipahami. Perilaku yang ditunjukan oleh tokoh dalam Kumpulan Cerpen Dilarang Mencintai Bunga-Bunga mampu memberikan dampak kepada siswa tidak hanya tentang bagaimana berperilaku yang baik saat di sekolah tetapi juga menhormati juga menyayangi orang tua dan saudara di rumah.

\section{SIMPULAN}

Berdasarkan hasil temuan penelitian dapat disimpulkan sebagai berikut. (1) ditemukan data permajasan sejumlah 69 data. Data permajasan tersebut merupakan data dari beberapa kelompok majas, yaitu simile sejumlah 8 , metafora sejumlah 10 , personifikasi sejumlah 13, alegori sejumlah 5, antitesis sejumlah 3, sarkasme sejumlah 5, epitet sejumlah 3 , hiperbola sejumlah 13, asonansi sejumlah 5, paradoks sejumlah 2, klimaks sejumlah 2, antiklimaks sejumlah 1 , sinisme sejumlah 3 , parafrasis sejumlah 2, pleonasme sejumlah 2.

Ada tiga majas yang dominan dalam novel Dilarang Mencintai Bunga-Bunga karya Kuntowijoyo, yaitu metafora 
,personifikasi, dan hiperbola .(2) Bahasa Indonesia kelas IX SMP adalah Berdasarkan analisis Citraan terdapat mengacu pada KD 3.3 di atas. terdapat beberapa analisis dari penggunaan Relevansinya dengan cara menganalisis citraan kumpulan cerita pendek Dilarang hasil pembahasan dengan kesesuaian Mencintai Bunga-Bunga jika di materi yang ada, baik itu struktur kalimat, prosentasekan citraan pengelihatan $37 \%$, ejaan, dan tanda baca. Hal ini menjadikan citraan pendengaran 22\%, citraan peserta didik mendapatkan ilmu baru dari penciuman 5\%, Citraan pengecapan 5\%. hasil pembahasan skripsi tersebut. Peserta (3) 3) Nilai pendidikan karakter berupa didik tidak hanya diberikan materi yang religius, mandiri, integritas, nasionalis dan sesuai dengan buku teks atau lembar tugas gotong royong yang terdapat dalam cerpen saja. Tapi dapat mengetahui hal lain dalam mampu memberikan pembelajaran kepada pembelajaran sastra berkaitan dengan pembaca tentang kehidupan sehari-hari.

Hasil penelitian yang berkaitan kajian stilistika.

dengan relevansi untuk pembelajaran 


\section{REFERENSI}

Aminuddin. (1995). Stilistika Pengantar Memahami Bahasa dalam Karya Sastra. Semarang: IKIP Semarang Press.

Ali, Ahmad, Herman J. Waluyo, \& Atikah Anindyarini. (2012). "Novel Pudarnya Pesona Cleopatra karya Habiburahman El-Zhirazy (Sebuah Tinjauan Stilistika). Basastra: Jurnal Penelitian Bahasa, Sastra Indonesia, dan Pengajarannya. 1(1): 252-238

Endraswara, S. (2003). Metodologi Penelitian Sastra. Yogyakarta: Pustaka Widyatama.

Nuroh, Ermawati Zulikhatin. 2011. Analisis Stilistika dama Cerpen. Pedagogia. Vol. 1, No. 1, hal 21-34, http://journal. umsida.ac.id/files/ErmaV1.1.pdf, diunduh tanggal 25 juni 2017.

Nurgiyantoro, Burhan. (2014). Teori Pengkajian Fiksi. Yogyakarta: Gajah Mada University Press

Peraturan Presiden No. 87 Tahun 2017 tentang Penguatan Pendidikan Karakter
Pradopo, R. D. (1993). Pengkajian Puisi Analisis Strata Norma dan Analisis Struktural dan Semiotik. Yogyakarta: Gadjah Mada University Press.

Ratna, N. K. (2009). Sastra dan Cultural Studies Representasi Fiksi dan Fakta. Yogyakarta: Pustaka Pelajar

Riris K. Toha-Sarumpaet. (2010). Pedoman Penelitian Sastra Anak, Edisi Revisi. Jakarta:Yayasan Pustaka Obor Indonesia

Keraf,G.(2007). Diksi dan gaya bahasa. Jakarta:PT Gramedia Pustaka Utama.

Krippendorrf,K. (2004). Content Analysis An Introduction to Its Methodology. Thousannd Oaks : Sage Publications

Sayuti A, Sumitno. 2000. Berkenalan dengan Prosa Fiksi. Yogyakarta: Gama Media

Wellek, Rene dan Austin Warren. (2014). Teori Kesusastraan. Diterjemahkan oleh Melani Budianta. Jakarta: PT Gramedia 